\title{
Use of GIS in Hydrogeochemical Study and Quality Status From Pudukkottai District, Tamil Nadu, India
}

\section{Muruganantham Arumugam}

Alagappa University Faculty of Science

Sivakumar Karthikeyan

Alagappa University Faculty of Science

Prabakaran Kulandaisamy ( $\sim$ prabakarank@alagappauniversity.ac.in )

Alagappa University Faculty of Science https://orcid.org/0000-0002-3393-8033

Kongeswaran Thangaraj

Alagappa University Faculty of Science

Venkatramanan Senapathi

Alagappa University

Bangaru Priyanga Sundaram

Alagappa University Faculty of Science

Agastheeswaran Vellaikannu

Alagappa Government Arts College

Perumal Velmayil

Alagappa University Faculty of Science

\section{Research Article}

Keywords: Hydrogeochemical, groundwater quality, DWQI, IRWQI and GIS

Posted Date: June 17th, 2021

DOI: https://doi.org/10.21203/rs.3.rs-577840/v1

License: (c) (i) This work is licensed under a Creative Commons Attribution 4.0 International License.

Read Full License 
Authors: Muruganantham $\mathrm{A}^{1}$, Sivakumar $\mathrm{K}^{1}$, Prabakaran $\mathrm{K}^{1}$, Kongeswaran $\mathrm{T}^{1}$, Venkatramanan $\mathrm{S}^{2}$, Bangaru Priyanga $\mathrm{S}^{1}$, Agastheeswaran $\mathrm{V}^{3,1}$ and Perumal $\mathrm{V}^{1}$

Title: Use of GIS in hydrogeochemical study and quality status from Pudukkottai District, Tamil Nadu, India Affiliation:

${ }^{1}$ Department of Geology, Alagappa University, Faculty of Science, Karaikudi-630003, India

${ }^{2}$ Department of Disaster Management, Alagappa University, Karaikudi-630003, India

${ }^{3}$ Department of Geology, Alagappa Govt. Arts College (Affiliated to Alagappa University), Karaikudi-630003, India

*Corresponding author email:prabakarank@alagappauniversity.ac.in

\title{
ORCID:
}

Muruganantham Arumugam: 0000-0002-2832-722X; Sivakumar Karthikeyan: 0000-0001-8164-1157;

Prabakaran Kulandaisamy: 0000-0002-3393-8033; Kongeswaran Thangaraj: 0000-0002-0752-8727;

Venkatramanan Senapathi: 0000-0002-1698-1101; Bangaru Priyanga Sundaram: 0000-0002-6346-4342;

Agastheeswaran Vellaikannu: 0000-0002-5360-6431; Perumal Velmayil: 0000-0002-5744-0870

\begin{abstract}
This study focused on hydrogeochemical characterisation and groundwater quality deterioration based on drinking, irrigation purposes in Pudukottai district. Eighty-seven groundwater samples were collected from the bore and dug wells during pre and post monsoon seasons in the year 2019. The order of mean abundance of ions is followed as C 1 $>\mathrm{HCO} 3>\mathrm{Na}>\mathrm{SO} 4>\mathrm{Mg}>\mathrm{Ca}>\mathrm{K}(325.5>182.2>181.4>83.2>51.1>35.8>9.1>8.6>0.9>0.3)$ and $\mathrm{Cl}>$ $\mathrm{Na}>\mathrm{HCO} 3>\mathrm{SO} 4>\mathrm{Mg}>\mathrm{Ca}>\mathrm{K}(415.7>230.3>198.2>82.9>53.8>43.4>14.9)$ in both seasons. Analytical results are used in Piper, Gibbs, Na\% vs. EC, USSL, and PI to evaluate the hydrogeochemical processes. Rock water interaction and evaporation processes causing variations in hydrogeochemistry of the study area during pre and postmonsoon. Nearly $15 \%$ of the groundwater samples were not permissible for drinking based on the standard, which is distributed in south eastern region of the study area. It is revealed from $\mathrm{Na} \%, \mathrm{SAR}, \mathrm{RSC}, \mathrm{MgC}$ and $\mathrm{KR}$ results that majority of the groundwater samples are fit for irrigation uses. The higher concentration of EC, TDS, $\mathrm{Cl}$ and $\mathrm{Na}$ values noted in south region due to the sea water intrusion that attributed by excess pumping in the coastal regions. The drinking water quality index (DWQI) and irrigation water quality index (IRWQI) are calculated to identify the suitability of groundwater for drinking and irrigation purposes. However, this research concludes that the groundwater quality of maximum part in the district is appropriate for drinking as well as agriculture which can be used for the sustainable growth. It is also recommended implementing the artificial recharge techniques to improve the groundwater quality.
\end{abstract}

Keywords: Hydrogeochemical, groundwater quality, DWQI, IRWQI and GIS 


\section{Declarations}

\section{Funding}

This article has been written with the financial support of RUSA - Phase 2.0 grant sanctioned vide letter No.

24-51/2014-U, Policy (TNMulti-Gen), Department of Education, Government of India, Dated. 09.10.2018.

\section{Conflicts of interest/Competing interests}

The authors declare that they have no competing interests.

\section{Availability of data and material}

The datasets used and/or analyzed during the current study are available from the corresponding author on reasonable request.

\section{Code availability}

Not applicable

\section{Authors' contributions}

Muruganantham Arumugam: conceptualization; methodology; writing-original draft preparation

Sivakumar Karthikeyan: conceptualization; methodology; writing- review and editing.

Prabakaran Kulandaisamy: supervision; writing-review and editing.

Kongeswaran Thangaraj: data collection, editing data processing and visual interpretations

Venkatramanan Senapathi: formal analysis and writing-review and editing

Bangaru Priyanga Sundaram: data processing and visual interpretations

Agastheeswaran Vellaikannu: conceptualization; methodology; writing-review and editing

Perumal Velmayil: data collection and editing

Ethics approval: Not applicable

Consent to participate: Not applicable

Consent for publication: All the authors have given their consent for the publication of this article 


\section{Use of GIS in hydrogeochemical study and quality status from Pudukkottai District, Tamil Nadu, India}

\section{Introduction}

Groundwater is a dynamic and replenishing natural resource, which forms the core of the ecological system. The emerging global freshwater crisis in terms of water quality and quantity is already felt in India. Quality of groundwater has particularly received immense attention since the groundwater is required for domestic and irrigation purpose (Prabakaran et al. 2020).Land and water are precious natural resources on which rely the sustainability of agriculture, industrialization and the civilization of mankind. Unfortunately, they have been subject to severe exploitation and contamination due to anthropogenic activities such as artisanal mining, industrial effluent, dumpsites, gas flaring, oil spillage and petroleum refining leading to the release of heavy metals into the aquatic environment (Nair et al. 2021). Groundwater is not only the most important resources for drinking purposes and it is also used extensively to satisfy agricultural, domestic and industrial water demands (Sivakumar et al. 2021). Generally, maximum crop yields management can be obtained based on the water quality and soil. In addition, the decrease of drinking water quality has been reported in many cases followed by groundwater contamination (Sivakumar et al. 2016; Ramachandran et al. 2020; Roy et al. 2021; Nair et al. 2021). Geochemical studies are widely used to understand the probable changes in groundwater quality (Arumugam and Elangovan 2009). Variation of groundwater chemistry mainly controlled by the factors of geology, chemical weathering intensity of rocks, recharging water quality and other inputs from anthropogenic sources (Adithya et al. 2021). These factors with their interactions result in a complex quality of groundwater in various aquifer system (Aghazadeh \& Mogaddam, 2010). The groundwater salinization is a major issue whichis triggered by seawater intrusion, agrochemical effluents, geogenic contamination and salinization induced by irrigation (Selvam et al. 2021). The rapid increase in the population of the country has led to large-scale groundwater depletion in some areas. Seasonal and spatial variations caused by condensation, dispersion, dissolution, oxidation, precipitation, reductions, sorption and volatilization are major geochemical processes (Sarath et al. 2012). To achieve the quality control and improvement, understanding these interrelated processes is very important due to their control over the chemistry of groundwater (Subba Rao et al. 2011).Modern GIS technology can be used to identify the groundwater potential zone (Agastheeswaran et al. 2021), portable zone (Prabakaran et al 2020) and to delineate the saline water from fresh water zone (Selvam et al. 2021). Water Quality index (WQI) approach is another important tool used to convert complex water quality data into easily interpretable form. It reports the overall quality of water at an allocation for the specific purposes (Chung et al. 2015; Venkatramanan et al. 2016). WQI integrated with GIS gives more precise and reliable results of spatial distribution of overall water quality (Venkatramanan et al. 2016; Ramachandran et al. 2020). For this purpose, we have approached the important research tasks such as (1) understanding the complex nature of hydrogeochemical process, (2) GIS techniques were used to determine the suitability for groundwater in the purpose of drinking and irrigation uses and (3) we investigated both natural and anthropogenic sources of this region. Also it appraised the updated scientific basis of groundwater quality deterioration and its sources in this region and may offer a treasured insight for future research. 


\section{Study area}

This region is situated between $78^{\circ} 25^{\prime}$ and $79^{\circ} 15^{\prime}$ east longitudes and between $9^{\circ} 50^{\prime}$ and $10^{\circ} 40^{\prime}$ of north latitudes. It is wide spread with an aerial extent of about 4,663sq.kmand a coastal stretch of $35 \mathrm{~km}$. The hard rocks are found on the western part and sedimentary formation found towards the eastern part. About $45 \%$ of the area is under hard massive formation of Archean age. Granitic gneiss, hornblende biotite gneiss, charnockites, pegmatite and quartzite are the various types of rocks encountered in this region and the rest 55\% comprises of the sedimentary formation ranging from pre-cambrian to quaternary period. Sedimentary deposits consist of clay, limestone, sand stone and clayey sandstone. The coastal alluvial deposits consist of unconsolidated sands, gravels and clay which are the major water bearing formations. The annual mean water level is varies between $0.58 \mathrm{~m}$ and $9.50 \mathrm{~m}$ below ground level. The transmissivity values in crystalline rock is $<1$ to $50 \mathrm{~m}^{2} /$ day whereas in sedimentary Rocks $600-4500 \mathrm{~m}^{2} /$ day in the study area (CGWB, 2008). Topography of the area general flattened; inter spread with small rocky hills which are numerous in the south-western parts of the district (Fig.1). Study area is the part of Cauvery basin and parts of sub basin in Vellar, Agniyar, Ambuliyar, Koraiyar, Gundar and Pambar. Vellar is the major river, which flows in an east-southeasterly direction and confluences with the Bay of Bengal near Manamelkudi. The average annual rainfall in the district is around $940 \mathrm{~mm}$ with temperatures going up to a maximum of $40^{\circ} \mathrm{C}$ during summer. In winter the minimum temperature is $20^{\circ} \mathrm{C}$ (Sirajudeen et al. 2015; Ponsingh and Maharani, 2015; Adithya et al. 2021).

Fig 1.The map shows the study area and sample location

\section{Materials and methods}

\section{Sampling and analysis}

Eighty-seven groundwater samples were collected from both the bore and dug wells in the study area during premonsoon and postmonsoon seasons in 2019 (Fig.1). Samples were filtered using $0.22 \mu \mathrm{m}$ membrane after transferred to laboratory. APHA (2017) procedures are followed to find out the physical parameters such as hydrogen ion activity $(\mathrm{pH})$, electrical conductivity (EC) and total dissolved solids (TDS) and the chemical parameters such as, Calcium $(\mathrm{Ca})$, Magnesium $(\mathrm{Mg})$, Sodium $(\mathrm{Na})$, Potassium $(\mathrm{K})$, Chloride $(\mathrm{Cl})$, Carbonate $\left(\mathrm{CO}_{3}\right)$, Bicarbonate $\left(\mathrm{HCO}_{3}\right)$, Sulphate $\left(\mathrm{SO}_{4}\right)$, Fluoride $(\mathrm{F})$ and total nitrate $\left(\mathrm{NO}_{2}+\mathrm{NO}_{3}\right)$. The ionic balance error was calculated as within $\pm 5 \%$.Standardized EDTA solution was used to measure the $\mathrm{Ca}$ and $\mathrm{Mg}$ concentrations. $\mathrm{AgNO}_{3}$ solution was standardized against $\mathrm{NaCl}$ of known concentration which was then used to estimate the $\mathrm{Cl}$ in samples. Hydro Chloric Acid (HCL) solution was used to determine the $\mathrm{CO}_{3}$ and $\mathrm{HCO}_{3}$. Flame Spectrometer of SYSTONIC model S-935 was used to determine the $\mathrm{Na} \& \mathrm{~K}$ and Sulphate (SO4) was determined by spectrophotometric turbidimetry (model-Labtronics LT-290).

\section{Interpretation}

The coordinates of each sampling site was obtained using a hand held GPS device of GARMIN model-etrex10 and loaded to ArcGIS v 10.2 platforms for the preparation of study area map (Fig.1). World Health Organisation (WHO, 2017) and the Bureau of Indian Standards (BIS, 2012) guideline values for drinking were used to compare the physico-chemical parameters for drinking and public health. Kriging interpolator of ArcGIS was used to plot the TDS values in a spatial map(Fig.2).Total Hardness (TH) (Eq.1), Sodium Absorption Ratio (SAR) (Eq.2), Sodium percentage (Na\%) (Eq.3), Residual Sodium Carbonate (RSC) (Eq.4), Permeability Index (PI) (Eq.5), Magnesium 
content (MgC) (Eq.6) and Kelly's Ratio (KR) (Eq.7) were calculated using excel spread sheet. The same was used to plot the PI diagram whereas, Piper, Gibbs, Wilcox USSL, Na\% vs. EC plotted using Aquachem software. The water quality index formula was followed from Ramachandran et al. (2020) and modified after Prabakaran et al. (2020) (Eq.8).

$$
\begin{aligned}
& \mathrm{TH}=\left(\mathrm{Ca}^{2+}+\mathrm{Mg}^{2+}\right) \mathrm{meq} / \mathrm{l} \times 50 \ldots \ldots \ldots . \mathrm{Eq}(1) \\
& \mathrm{SAR}=\frac{\mathrm{Na}^{+}}{\sqrt{\left(\mathrm{Ca}^{2+}+\mathrm{Mg}^{2+}\right) / 2}} \ldots \ldots \ldots \ldots \ldots \ldots \ldots \ldots \text {. Eq }(2) \\
& \mathrm{Na} \%=\frac{\left(\mathrm{Na}^{+}+\mathrm{K}^{+}\right) \times 100}{\left(\mathrm{Ca}^{2+}+\mathrm{Mg}^{2+}+\mathrm{Na}^{+}+\mathrm{K}^{+}\right)} \ldots \ldots \ldots \ldots \ldots . . . . . . . .2 \text { (3) }
\end{aligned}
$$

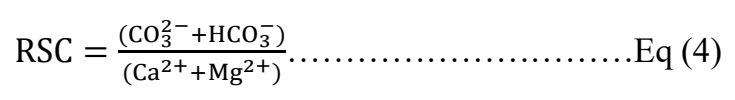

$$
\begin{aligned}
& \mathrm{PI}=\frac{\left(\mathrm{Na}^{+}+\sqrt{\mathrm{HCO}_{3}^{-}}\right) \times 100}{\left(\mathrm{Ca}^{2+}+\mathrm{Mg}^{2+}+\mathrm{Na}^{+}\right)} \ldots \ldots \ldots \ldots \ldots \ldots . . . . . . . . .(5) \\
& \operatorname{MgC}=\frac{\left(\mathrm{Mg}^{2+}\right) \times 100}{\left(\mathrm{Ca}^{2+}+\mathrm{Mg}^{2+}\right)} \ldots \ldots \ldots \ldots \ldots \ldots \ldots . . . \ldots q(6) \\
& \mathrm{KR}=\frac{\mathrm{Na}^{+}}{\left(\mathrm{Ca}^{2+}+\mathrm{Mg}^{2+}\right)} \ldots \ldots \ldots \ldots \ldots \ldots \ldots \ldots \mathrm{Eq}(7) \\
& \mathrm{WQI}=\sum\left[\frac{\mathrm{Wi}}{\sum_{\mathrm{i}=1}^{\mathrm{n}} \mathrm{Wi}}\right] \times \mathrm{qi} \ldots \ldots \ldots \ldots \ldots \ldots . . . \mathrm{Eq}(8)
\end{aligned}
$$

Where 'wi' is the assigned weightage for selected parameters and ' $n$ ' is the number of parameters selected for WQI assessment. The 'qi' denotes the ranking assigned for class range based on the standards for drinking and irrigation. The standard range of values provided by WHO and BIS was taken to derive the drinking water quality index (DWQI), whereas for the derivation of irrigation water quality index (IRWQI), the irrigation water quality parameters such as $\mathrm{EC}, \mathrm{TDS}, \mathrm{TH}, \mathrm{Na} \%, \mathrm{SAR}, \mathrm{MgC}, \mathrm{RSC}$ and $\mathrm{KR}$ were taken. All the plots are integrated with the ArcGIS v10.2 to determine the spatial pattern for the classification of hydrogeochemical plots (Fig. 3 to 8 ).

\section{Results and discussion}

The statistical summary of all the groundwater parameters are given in the Table (1) and the spatial distribution of the total dissolved solids with the spatial pattern of all the major ions are shown in the Figure (2) as pie charts in the map.

Table 1. Statistics of the water quality parameters in both seasons

Table 2. Water quality standards for drinking based on WHO and BIS

\section{Drinking quality}

\section{Physical constituents}

\section{Hydrogen ion activity (pH)}

The $\mathrm{pH}$ value is ranging between 7.0 and 8.4 with a mean value of 7.7in premonsoon and the same is ranging between 7.0 and 8.8 with a mean value of 8.33 during postmonsoon. The groundwater quality is good for drinking based on the premonsoon pH values when compared with WHO (2017) and BIS (2012) guideline values. However a small part in the northern and in the south-western region which shows higher $\mathrm{pH}$ values $(>8.5)$ caused by the mining 
leaches mixed with groundwater and addition to the seawater input in south-western coastal region during postmonsoon (Venkatramanan et al. 2016).It is found that most of the water plant companies are located around the southern part.

\section{Total Dissolved Solids (TDS)}

TDS levels of above $2000 \mathrm{mg} / \mathrm{L}$ are unsuitable and not suggested for drinking purpose (Table 2).TDS levels of more than $3000 \mathrm{mg} / \mathrm{L}$ affected the agricultural land (Table 3). Premonsoon TDS values are ranging from 78 to $7248 \mathrm{mg} / \mathrm{L}$ with an average of $822 \mathrm{mg} / \mathrm{L}$, whereas it is varying from 145 to $5938 \mathrm{mg} / \mathrm{L}$ with an average $982 \mathrm{mg} / \mathrm{L}$ during postmonsoon. In premonsoon season $45.97 \%$ sample, are desirable for drinking and $26.43 \%$ samples are permissible for drinking, $24.13 \%$ samples are useful for irrigation and 3.44\% samples are unfit for irrigation. In case of premonsoon, southwest part is having high TDS values due to agricultural activities (Sivakumar et al. 2016). While postmonsoon season 37.93 and $29.88 \%$ of samples are desirable and permissible limit for drinking purpose and 27.58\% samples are useful for irrigation, $4.5 \%$ samples are unfit for irrigation. North and south-eastern part are having high TDS value exhibit the mining activity and saline water intrusion due to the mining dump sites and over exploitation(Fig. 2).

Fig 2. Spatial distribution map shows the TDS with major ions as pie chart

\section{Electrical Conductivity (EC)}

The total ionized constituent of natural water is generally indicated by the EC values and is directly connected to the total cations and anions. In other hand, it is directly proportional to the value of total dissolved solids (Prabakaran et al. 2020). The minimum, maximum and average EC values determined is $150,11340 \& 1411 \mu \mathrm{S} / \mathrm{Cm}$ and 270 , $10170 \& 1699.1 \mu \mathrm{S} / \mathrm{Cm}$ in pre and postmonsoon seasons, respectively. During premonsoon $3.44 \%$ sample are excellent and 39\% samples are good for irrigation purpose respectively,37.8\% samples are permissible for irrigation, $16.09 \%$ samples are doubtful and 3.44\% sample are unsuitable for irrigation. While,33.33\% samples are good for irrigation purpose, $40.22 \%$ samples are permissible for irrigation, $13.79 \%$ samples are doubtful for irrigation and $12.64 \%$ samples are unsuitable for irrigation purpose in postmonsoon season (Table 3). This is attributed by dissolution of minerals from the aquifer media by intrusion of seawater increases the dissolved solids in groundwater which leads to increased EC value (Ramachandran et al. 2020).

\section{Chemical constituents}

\section{Calcium (Ca) and Magnesium (Mg)}

In premonsoon season, the Ca content is ranging between 10 and $116 \mathrm{mg} / \mathrm{L}$. While in postmonsoon season, it is varied from $8 \mathrm{mg} / \mathrm{L}$ to $224 \mathrm{mg} / \mathrm{L}$. In case of premonsoon season $90.80 \%$ sample, are excellent for drinking and 9.19\% samples are permissible for drinking, most of the sample are good for drinking purpose. $85.05 \%$ of samples are excellent for drinking and $13.79 \%$ samples are permissible for drinking, some of the samples shows high $\mathrm{Ca}$ values in the area of northern part during the postmonsoon (Fig.2). Mg concentration in groundwater is varied between $8.51 \mathrm{mg} / \mathrm{L}$ and $359.64 \mathrm{mg} / \mathrm{L}$ during premonsoon and the same is between $10.9 \mathrm{mg} / \mathrm{Land} 233.28 \mathrm{mg} / \mathrm{Lin}$ postmonsoon season. During premonsoon season $45.97 \%$, samples are excellent, $42.52 \%$ samples are good and 9.19\% samples are poor for drinking purpose. In postmonsoon season, 39.08\% samples are excellent followed by 45.97\% and 14.94\% samples are permissible and poor for drinking purpose. High Mg content was found in the 
northern and southwest part in postmonsoon, whereas central part of the study area is affected by $\mathrm{Mg}$ in premonsoon season. Due to the mineral dissolution from the host rocks (Nair et al. 2021).

\section{Sodium (Na) and Potassium (K)}

Sodium is the important element for plants and animals though it is required to maintain the metabolic activities (ref). During postmonsoon, groundwater samples $\mathrm{Na}$ is ranges from 6 to $1916 \mathrm{mg} / \mathrm{L}$ and from 1 to $1766 \mathrm{mg} / \mathrm{L}$ in premonsoon. Na affected in the region of western, southeast and small patches of southwest regions in premonsoon. While postmonsoon season, few location affected by $\mathrm{Na}$ and distributed in western part of the area. The concentration of $\mathrm{K}$ is ranging from 0.1 to $168 \mathrm{mg} / \mathrm{L}$ and from 0.1 to $117 \mathrm{mg} / \mathrm{L}$ in pre and postmonsoon seasons. The trend of $\mathrm{K}$ concentration is increasing towards east in premonsoon and increasing towards west in postmonsoon. The higher concentration of $\mathrm{Na}$ and $\mathrm{K}$ may be originated from seawater intrusion and fertilizer (Venkatramanan et al. 2016).

\section{Chloride (Cl)}

Natural waters contain $\mathrm{Cl}$ a major dissolved constituent which is also used as good indicator of water quality (Sarath et al. 2012). Cl concentration in groundwater ranges between 32 and $2836 \mathrm{mg} / \mathrm{L}$ and between 18 and $4013 \mathrm{mg} / \mathrm{L}$ in pre and postmonsoon seasons, respectively. In case of premonsoon season, 59.10\% samples are excellent, 36.78\% are good and $4.59 \%$ samples are poor for drinking. In postmonsoon season $52.87 \%$ sample are excellent for drinking, 37.93\% samples are permissible and 9.19\% samples are poor for drinking (WHO, 2008; BIS, 2012). Groundwater of the southeast part is contaminated by $\mathrm{Cl}$ in premonsoon. While postmonsoon season, high $\mathrm{Cl}$ was found in the northern part and south-eastern part. Higher concentration of $\mathrm{Cl}$ ion in groundwater may point out the significant influences of seawater intrusion and fertilizer waste. High concentration of $\mathrm{Cl}$ may be harmful to human health such as heart, kidney, indigestion and palatability (CPCB, 2008).

\section{Carbonate $\left(\mathrm{CO}_{3}\right)$ and Bicarbonate $\left(\mathrm{HCO}_{3}\right)$}

The $\mathrm{CO}_{3}$ level is ranges from BDL (below detectable limit) to $12 \mathrm{mg} / \mathrm{L}$ in premonsoon and it is varies from BDL to $36 \mathrm{mg} / \mathrm{L}$ in postmonsoon. Bicarbonate and carbonate levels of $<120 \mathrm{mg} / \mathrm{L}$ and $<15 \mathrm{mg} / \mathrm{L}$ can react with $\mathrm{Ca}$ and $\mathrm{Mg}$ of soil compounds and forms insoluble lime such as $\mathrm{CaCO}_{3}$ and $\mathrm{MgCO}_{3}$ (Kuttymani et al. 2017). The $\mathrm{HCO}_{3}$ value is range between 44.26 and $695.4 \mathrm{mg} / \mathrm{L}$ with the mean value of $182.2 \mathrm{mg} / \mathrm{L}$ in premonsoon. The postmonsoon $\mathrm{HCO}_{3}$ value varies from 9.64 to $768.6 \mathrm{mg} / \mathrm{L}$ with the mean value of $198.17 \mathrm{mg} / \mathrm{L}$. Bicarbonate values are increased due to the presents of carbonate rocks noted in central, south and south-western direction. The high level of $\mathrm{HCO}_{3}$ north-eastern side in postmonsoon while premonsoon season is shifted to northwest and central (Fig.2). The increase in $\mathrm{HCO}_{3}$ concentration may be attributed to dissolution of $\mathrm{CO}_{2}$ gas in the air or soil. This is a common process in arid and semi-arid agricultural region (Nazzal et al. 2014).

\section{Sulphate $\left(\mathrm{SO}_{4}\right)$}

$\mathrm{SO}_{4}$ concentration of groundwater samples ranged from 5 to $480 \mathrm{mg} / \mathrm{L}$ and varied from 3 to $576 \mathrm{mg} / \mathrm{L}$ in both season. $87.35 \%$ samples are excellent for drinking, $8.04 \%$ samples are good and $4.59 \%$ samples are poor for drinking purpose during premonsoon. During postmonsoon season, $95.40 \%$ samples are excellent for drinking, $3.44 \%$ samples are permissible and $1.14 \%$ samples are poor condition. $\mathrm{SO}_{4}$ concentration noted in southeast and western part of the area in pre and postmonsoon seasons, respectively. $\mathrm{SO}_{4}$ may be originated from multiple ways, 
i.e. dissolution and oxidation of sulphate and sulphide minerals, intrusion of seawater and sources from anthropogenic origin (Srinivasamoorthy et al. 2014).

\section{Fluoride (F)}

Fluoride content is ranges between 0.05 and $1.0 \mathrm{mg} / \mathrm{L}$ during premonsoon and the same is ranges between 0.05 and $1.63 \mathrm{mg} / \mathrm{L}$ during postmonsoon. In premonsoon season, $97.70 \%$ and $2.29 \%$ samples are excellent and are good for drinking uses. In postmonsoon season $93.10 \%, 5.74 \%$ and $1.14 \%$ samples are excellent, permissible and poor for drinking purpose. During postmonsoon period, F content is high in the northern part because of dissolution of fluoride baring granitic rocks that are present in the study area is the source for the enrichment of the groundwater (Kalpana et al. 2019).The excess fluoride in groundwater as being the only source of fresh water in drinking purposes may leads to the dental fluorosis condition to the people.

\section{Total Nitrogen $\left(\mathrm{NO}_{2}+\mathrm{NO}_{3}\right)$}

The total nitrogen concentration in groundwater samples ranges between $0.05 \mathrm{and} 84 \mathrm{mg} / \mathrm{L}$ with a mean of 8.57 $\mathrm{mg} / \mathrm{L}$. Also, it ranges between $0.1 \mathrm{and} 45 \mathrm{mg} / \mathrm{L}$ with the mean of $6.37 \mathrm{mg} / \mathrm{L}$ in pre and postmonsoon season, respectively. Atmospheric nitrogen gas is mineralised by soil bacteria and converted into ammonium. Further the nitrifying bacteria under aerobic conditions convert it into nitrate hence the origin for the concentration of nitrogen in groundwater is biosphere (Tindall et al. 1995; Saleh et al. 1999).

\section{Total hardness classification}

Even though water hardness was not identified for hostile effects, some specific indication relates it in heart sickness (WHO, 2008). Hard water stands inappropriate for general use and it has a degree of the $\mathrm{Ca}^{2+}$ and $\mathrm{Mg}^{2+}$ concentration expressed in equivalent of calcium carbonate. The measure of water that react with soap compound and precipitate $\mathrm{Ca}^{2+}$ and $\mathrm{Mg}^{2+}$ as carbonates, chlorides and sulphates is defined as hardness of water. The presence of $\mathrm{CaCO}_{3}$ is released from boiling water is measured as temporary hardness whereas the removal of $\mathrm{Ca}^{2+}$ and $_{\mathrm{Mg}^{2+}}$ ions only by means of ion exchange processes is called as permanent hardness (Srinivasamoorthy et al. 2014). Scaling on pots, boilers and irrigation pipes are caused by water hardness which limits its usage in industries and also causes kidney failure problems to the human health (WHO 2008). Equation (1) was proposed by Todd 1980 to determine the total hardness. During premonsoon, TH ranges between 60 and $1740 \mathrm{mg} / \mathrm{L}$ with a mean $299.62 \mathrm{mg} / \mathrm{L}$ and representing $29.87 \%$ of the groundwater samples beyond the soft and moderate level. In postmonsoon, TH varies between 85 and $1,520 \mathrm{mg} / \mathrm{L}$ with mean value of $329.24 \mathrm{mg} / \mathrm{L}$ and representing $20.68 \%$ of the samples exceeding the soft and moderate limit (Table 3). It has inferred that, both the seasons records moderate TH as permanent hardness due to the mining and industrial activities in eastern coastal region (Sivakumar at al. 2016).

Table 3 Groundwater suitability for irrigation as per the quality parameters

\section{Hydrogeochemical processes}

\section{Different facies of hydrogeochemical process}

Piper diagram (Fig. 3) was developed to understand water chemistry of different hydrogeological facies. The difference or dominance of cation and anion in the groundwater is explained by the Piper diagram in both seasons. The higher percentage of samples falling under the second broad category of alkali earth $(\mathrm{Na}+\mathrm{K})$ exceeds alkaline earth $(\mathrm{Ca}+\mathrm{Mg})$ was $53.75 \%$ during the premonsoon and $54.02 \%$ in postmonsoon. The strong acids $(\mathrm{SO} 4+\mathrm{Cl})$ 
exceeds weak acids is the forth broad and dominant category which holds $90 \%$ and $94.25 \%$ in both seasons. The non-carbonate alkali exceeds $50 \%(\mathrm{Na}+\mathrm{Cl})$ is the dominant water type in pre and postmonsoon season of groundwater samples which is about $51.25 \%$ and $54.04 \%$ respectively. This water type causes the primary salinity to the groundwater of the study area. No one cation-anion pair exceeds $50 \%$ is the second dominant water type with $37.75 \%$ in premonsoon and $34.48 \%$ in postmonsoon season. The carbonate hardness exceeds $50 \%\left(\mathrm{Ca}+\mathrm{Mg}+\mathrm{HCO}_{3}\right)$ water type exist about $7.5 \%$ followed by $3.75 \%$ of non-carbonate hardness exceeds $50 \%\left(\mathrm{Ca}+\mathrm{Mg}+\mathrm{SO}_{4}\right)$ water type during premonsoon. Whereas, same water types exist during postmonsoon as $4.59 \%$ and $6.89 \%$ respectively. These water types are causing the secondary alkalinity and secondary salinity to the groundwater. Carbonate alkali exceeds $50 \%\left(\mathrm{Na}+\mathrm{HCO}_{3}\right)$ water type causes the primary alkalinity to the groundwater. It is lead by the dissolution of minerals from the weathered rocks and recharge by precipitation processes. The primary salinity maybe attributed by the seawater intrusion or by the formation salt in the coastal regions of the district. The samples has classified based on the Piper diagram and spatially shown on the geology map of the study area (Fig.3). It clearly shows the correlation between the water type and rock types that present in the study area.

Fig 3. Piper plot for both seasons with spatial distribution maps of hydrological facies

\section{Mechanism controlling the groundwater processes}

Three major mechanisms such as evaporation, precipitation and rock water interaction are the processes controlling the water quality derived from the Gibbs (1970) diagram. Gibbs diagram shows $73.75 \%$ of the groundwater samples fall between 100 and 1000 (mg/L) TDS in premonsoon signifying the rock water interaction is the main controlling factor in the study area. Whereas in postmonsoon season, evaporation (67.82\%) process is followed by rock water interaction (32.18\%) are the dominant controlling factors. Weathering of host rock silicate minerals are contributing towards the enrichment of water variation in aquifers (Venkatramanan et al. 2016). The lower concentration of $\mathrm{Ca}$ and $\mathrm{Mg}$ in groundwater is due to the lower concentration of carbonate minerals in the lithology of the region, though $\mathrm{Na}$ and $\mathrm{K}$ values show that silicate weathering followed by hard rock weathering (Chung et al. 2015). Many samples poses carbonate of below detectable limit however, bicarbonate is found present in all the samples during both seasons (Fig.4).

Fig 4. Gibb's plot for both seasons with spatial distribution map of influencing factors

\section{Irrigation quality}

\section{Sodium percentage $(\mathrm{Na} \%)$}

Sodium reacts with soil and reduces its permeability makes it as a significant ion studied to classify the water quality for irrigation. It is generally denoted as soluble sodium percentage or percent sodium (\% $\mathrm{Na}$ ) and is widely used to assess the water suitability for irrigation purposes (Wilcox, 1955; Todd, 1980; Islam et al. 2017). The ratio of Na and the total cations present in the water is computed as $\mathrm{Na} \%$ where all values are calculated in meq/L. The sodium percentage values shows that only $3.44 \%$ of the pre and post monsoon samples are excellent $(<20)$ for irrigation. Whereas $42.53 \%$ and $37.94 \%$ in total samples respective to pre and post monsoon are falls under permissible (40-60) category for irrigation. In premonsoon $4.59 \%$ and in postmonsoon $2.29 \%$ samples are unsuitable for irrigation purpose (Table 3). Higher $\mathrm{Na} \%$ is representing the ascendancy of ion exchange and weathering from host rocks. Plotting the $\mathrm{Na} \%$ against the EC gives a better understanding of the water suitability for irrigation (Wilcox 
1955).Land use and land cover map is used as a base layer to overlay the obtained classes from Na\% vs. EC plot for irrigation purposes (Fig.5).

Fig 5. Na\% vs. EC plot for both seasons with irrigation suitability map

\section{Sodium Adsorption Ratio (SAR)}

SAR is used to determine the sodium hazard for irrigation waters though it is used to find the suitability of groundwater for irrigation, where it measures the alkali or sodium hazard to crops. Increase in SAR value leads to increase the sodium hazard and decrease the water quality for irrigation uses. The dispersion and flocculation of sodium and specific conductance affects the soil infiltration rates through the irrigation water (Aghazadeh \& Mogaddam, 2010). Irrigation water with larger SAR values can't be tolerated by soils. The study area SAR values are ranging from 18.42 to 27.78 with a mean value of 4.40 and from 0.238 to 8.16 with a mean value of 5.18 in pre and postmonsoon seasons, respectively. SAR value classified as $83.9 \%$ excellent $(>10), 14.94 \%$ good for irrigation purpose (10-18) and 1.14\% doubtful (18-26) for irrigation purpose in premonsoon. While postmonsoon, SAR value classified as $87.35 \%$ excellent (>10),10.34\% good (10-18), and $2.29 \%$ doubtful (18-26)for irrigation uses. This shows that crops in the study area do not have alkali hazards. US salinity diagram (USSL) illustrates the SAR values against the EC values to classify the water quality for irrigation purposes (Fig.6). According to the USSL classification plot the sodium and salinity hazard class is followed as $\mathrm{C} 2 \mathrm{~S} 1>\mathrm{C} 3 \mathrm{~S} 1>\mathrm{C} 3 \mathrm{~S} 2>\mathrm{C} 4 \mathrm{~S} 2=\mathrm{C} 4 \mathrm{~S} 3>\mathrm{C} 4 \mathrm{~S} 1>\mathrm{C} 1 \mathrm{~S} 1=\mathrm{C} 4 \mathrm{~S} 4>\mathrm{C} 3 \mathrm{~S} 3=\mathrm{C} 3 \mathrm{~S} 4$ in premonsoon and in postmonsoon it is ordered as $\mathrm{C} 2 \mathrm{~S} 1>\mathrm{C} 3 \mathrm{~S} 1>\mathrm{C} 3 \mathrm{~S} 2>\mathrm{C} 4 \mathrm{~S} 3>\mathrm{C} 4 \mathrm{~S} 2>\mathrm{C} 4 \mathrm{~S} 1>\mathrm{C} 4 \mathrm{~S} 4=\mathrm{C} 3 \mathrm{~S} 3$. The result shows that medium to high saline groundwater with low to medium alkali hazard $(\mathrm{C} 2 \mathrm{~S} 1+\mathrm{C} 3 \mathrm{~S} 1=67.5 \%$ and $57.47 \%$ respectively) in both seasons. The sodium hazard and salinity hazard classification result have overlaid on the study area geology map (Fig.6).

Fig 6. USSL plot for both seasons with spatial distribution map classes

\section{Residual Sodium Carbonate (RSC)}

The rise of carbonate and bicarbonate values over calcium and magnesium concentration is alarming to the soil fertility and plants growth (Brindha et al. 2013) hence it is used to decide the appropriateness of water for irrigation. The RSC values during premonsoon are ranging between 0.023 and $1.49(\mathrm{meq} / \mathrm{L})$ with a mean value of $0.7(\mathrm{meq} / \mathrm{L})$. While postmonsoon RSC values are varies from 0.025 to 2.99 and the average value is 0.95 . Overall96.56\% and $93.12 \%$ in pre and postmonsoon seasons, respectively with the groundwater samples fall below $1.25 \mathrm{meq} / \mathrm{L}$ and are suitable for irrigation (Srinivasamoorthy et al. 2014).

\section{Permeability Index (PI)}

Doneen (1964) plotted PI against total salt concentration and divided into three water quality class. Class I indicate the $100-75 \%$ soil permeability exhibit suitable for irrigation. Whereas class II indicates $75-25 \%$ soil permeability which is moderately suitable for irrigation and class III is $<25 \%$ reveals unsuitable for irrigation uses. Results show that81 samples falls in class I and II and all the samples fall in class I to II in pre and postmonsoon seasons, respectively. Comparing PI value of both seasons, more than $90 \%$ of the samples fall in class I and class II shows suitability groundwater for irrigation however $2.2 \%$ samples are falls under class III in premonsoon. Five different types of soils present in the study area, which are Ap-Plinthic Acrisols, Rc-Calcaric Regosols, Lc-Chromic Luvisols, 
Lo-Orthic Luvisols and Vc-Chromic Vertisols (IUSS Working Group WRB, 2015). The soil type map has used as base layer to overlay the class derived from the PI vs. TSC plot (Fig.7).

Fig 7. Doneen's PI plot for both seasons with spatial distribution map of classes

\section{Magnesium Content (MgC)}

Most of the groundwater generally shows equilibrium state between $\mathrm{Ca}^{2+}$ and $\mathrm{Mg}^{2+}$ ions (Hem 1985). Since, increase in $\mathrm{Mg}^{2+}$ ions collapses this equilibrium and impacts the soil quality by increasing its alkalinity which ultimately decreases the crop yield (Kumar et al. 2007). The magnesium hazard is calculated using an index proposed by Paliwal (1972). The $\mathrm{MgC}$ ranges from 8.51 to $359.64 \mathrm{mg} / \mathrm{L}$ and 10.9 to 233.28 for premonsoon and postmonsoon season respectively. During premonsoon 57 samples and in postmonsoon 55 samples falls over the allowable value of $50 \mathrm{mg} / \mathrm{L}$ representing the increased soil alkalinity and leads to adverse effect on crop yield. Those samples would adversely affect the crop yield by making the soil more alkaline (Paliwal, 1972).

\section{Kelly's Ratio (KR)}

Kelly's ratio is used to divide the water quality as either suitable or unsuitable for irrigation uses. Sodium measured against total calcium and magnesium is considered as Kelly's ratio (KR). KR of above (KR>1) indicates an excess level of sodium in waters (Kelly, 1940). Therefore, waters with a KR of $<1$ is fit for irrigation, while waters those with KR<1 are unfit for irrigation (Sundaray et al. 2009). KI values varied between 0.31 to 14.71 and 0.41 to 6.43 in pre and postmonsoon seasons, respectively. According to the KR classification 54.02\% samples present in premonsoon and $50.57 \%$ of samples fall in postmonsoon which indicates the suitable limit for irrigation purpose.

\section{Combined overlay water quality index}

To precisely find out the overall suitability of groundwater for drinking as well as irrigation purpose, the weighted arithmetic Water Quality Index (WQI) method was used. The selected analytical and calculated parameters with its weight and relative weight percentage has given in Table 4 for drinking water quality index (DWQI) and in Table 5 for irrigation water quality index (IRWQI). Inverse distance weighted interpolation technique in ArcGIS was applied for each selected parameters and reclassified based on the water quality ranking scale as given table $4 \& 5$. All the reclassified layers were processed in weighted overlay analysis of ArcGIS module with the relative weight percentage of respective parameters to derive the DWQI map and IRWQI map. The derived DWQI and IRWQI values are ranges between 1 to 3 and 1 to 5 respectively.

Table 4. Relative weights for drinking WQI based on WHO \& BIS standards

Table 5. Relative weights for IRWQI based on irrigation water quality parameters

Quantile classification method was applied for both WQI maps and the area of water quality classification based on derived mapsare shown in Table 6 and 7 respectively. The DWQI classification shows that, $56.06 \%$ (premonsoon) and 56.19\% (postmonsoon) in total study area is poses groundwater suitable for drinking uses both seasons. Whereas, IRWQI classification exhibits $51.78 \%$ (premonsoon) and $45 \%$ (postmonsoon) of the samples are suitable for irrigation uses in both seasons. Spatial variation of DWQI and IRWQI of shows that south-eastern, north and north-western parts of the study area which more affected by pollutants from anthropogenic sources, seawater intrusion and anthropogenic runoff. While southern and central part exhibits unpolluted in both monsoons which is 
suitable for drinking as well as irrigation purposes. By implementing artificial recharge structures in thegroundwater contaminated area will improve the quality and will make it suitable for both purposes.

Fig 8. Spatial distribution maps of calculated DWQI \& IRWQI for both seasons

Table 6 Drinking Water Quality Index (DWQI) class for Pudukottai district

Table 7 Irrigation Water Quality Index (IRWQI) class for Pudukottai district

\section{Conclusion}

Groundwater quality in both seasons is mostly suitable for drinking uses when comparing the analytical results with the proposed drinking water guidelines. The abundance sequence of ions was in the following order: $\mathrm{Cl}>\mathrm{HCO}_{3}>\mathrm{Na}>\mathrm{SO} 4>\mathrm{Mg}>\mathrm{Ca}>\mathrm{K}$ and $\mathrm{Cl}>\mathrm{Na}>\mathrm{HCO}_{3}>\mathrm{SO}_{4}>\mathrm{Mg}>\mathrm{Ca}>\mathrm{K}$ in pre and postmonsoon seasons. In case of calculated values of irrigation water quality parameters ( $\mathrm{TH}, \mathrm{Na} \%$, SAR, RSC, PI, $\mathrm{MgC}$ and $\mathrm{KR}$ ) show that the majority of the groundwater samples are appropriate for irrigation and it also verified by comparing the EC and TDS values. Alkali earth exceeds alkaline earth and strong acids exceed weak acids are the dominant hydrogeological facies which is followed by non-carbonate alkali exceeds $50 \%$ facies water type in both monsoons. Gibbs plot shows evaporation and rock water interaction are the major controlling factors of the hydrogeochemistry. The comprehensive WQI technique was used to know the groundwater suitability for drinking and irrigation uses. The DWQI and IRWQI spatial maps of higher concentration exhibits the south-eastern, north and north-western parts which is controlled by seawater intrusion and irrigation inputs. While southern and central part shows unpolluted zones. The characteristics of groundwater in this region were primarily due to the natural processes such as mineral dissolution, ion exchange, and leaching. Secondarily, the area was affected by seawater intrusion, mining activities, fertilizer and pesticide inputs increased the degradation of the groundwater quality. Groundwater quality can be improved in this region by implementing the groundwater management scheme of artificial recharge that ensures sustainable and non-hazardous groundwater resources for drinking, agriculture, and domestic purposes.

\section{Funding}

This article has been written with the financial support of RUSA, Phase 2.0 grant sanctioned vide letter No. 2451/2014-U, Policy (TNMulti-Gen), Department of Education, Government of India, dated September 10, 2018.

\section{Reference}

Adithya VSP, Chidambaram S, Prasanna MV, Venkatramanan S, Tirumalesh K, Thivya C, Thilagavathi R (2021) Health Risk Implication and Spatial Distribution of Radon in Groundwater Along the Lithological Contact in South India. Archives of Environmental Contamination and Toxicology, 80(1), 308-318. https://doi.org/10.1007/s00244020-00798-9

Agastheeswaran V, Udayaganesan P, Sivakumar K, Venkatramanan S, Prasanna Mohan V, Selvam S (2021) Identification of groundwater potential zones using geospatial approach in Sivagangai district, South India. Arabian Journal of Geosciences, 14(1), 8. https://doi.org/10.1007/s12517-020-06316-4

Aghazadeh N, Mogaddam AA (2010) Assessment of Groundwater Quality and its Suitability for Drinking and Agricultural Uses in the Oshnavieh Area, Northwest of Iran. Journal of Environmental Protection, 01(01), 30-40. https://doi.org/10.4236/jep.2010.11005 
APHA (2017) Standard methods for the examination of water and waste water, $23^{\text {rd }}$ edn. E.W. Rice, R.B. Baird, A.D. Eaton, editors, American Public Health Association, American Water Works Association, Water Environment Federation, Washington

Arumugam K, Elangovan K (2009) Hydrochemical characteristics and groundwater quality assessment in Tirupur region, Coimbatore district, Tamil Nadu, India. Environ Geol 58:1509-1520

BIS 2012. Indian standard drinking water specification IS: 10500. Bureau of Indian Standards, New Delhi.

Brindha K, Neena Vaman KV, Srinivasan K, Sathis Babu, M, Elango L (2013) Identification of surface watergroundwater interaction by hydrogeochemical indicators and assessing its suitability for drinking and irrigational purposes in Chennai, Southern India. Applied Water Science, 4(2), 159-174. https://doi.org/10.1007/s13201-0130138-6

CGWB (2008) District groundwater brochure- Sivaganga District, TAMIL NADU, Central Groundwater Board, South Eastern Coastal Region.

Chung SY, Venkatramanan S, Kim TH, Kim DS, Ramkumar T (2015) Influence of hydrogeochemical processes and assessment of suitability for groundwater uses in Busan City, Korea. Environment, Development and Sustainability, 17(3), 423-441. https://doi.org/10.1007/s10668-014-9552-7

CPCB (2008) Guideline for water quality management. Central Pollution Control Board, Parivesh Bhawan Doneen LD (1964) Water quality for Agriculture. Department of Irrigation, University of California, Davis, p 48

Gibbs RJ (1970) Mechanisms controlling world's water chemistry. Science 170:1088-1090

Hem JD (1985) Study and interpretation of the chemical characteristics of natural water, USGS water supply Paper2254, p 2641

Islam SMDD, Majumder RK, Uddin MJ, Khalil MI, Ferdous Alam M (2017) Hydrochemical Characteristics and Quality Assessment of Groundwater in Patuakhali District, Southern Coastal Region of Bangladesh. Exposure and Health, 9(1), 43-60. https://doi.org/10.1007/s12403-016-0221-y

IUSS Working Group WRB (2015) World Reference Base for Soil Resources 2014, update 2015 International soil classification system for naming soils and creating legends for soil maps. World Soil Resources Reports No. 106. FAO, Rome

Kalpana L, Brindha K, Elango L (2019) FIMAR: A new Fluoride Index to mitigate geogenic contamination by Managed Aquifer Recharge. Chemosphere, 220, 381-390. https://doi.org/10.1016/j.chemosphere.2018.12.084

Kelly WP (1940) Permissible composition and concentration of irrigated waters. In: Proceedings of the ASCF66. p. 607

Kumar M, Kumari K, Ramanathan AL, Saxena R (2007) A comparative evaluation of groundwater suitability for irrigation and drinking purposes in two intensively cultivated districts of Punjab, India. Environ Geol 53:553-574. https://doi.org/10.1007/s00254-007-0672-3

Kuttimani R, Raviraj A, Pandian BJ, Kar G (2017) Chemical Science Review and Letters Determination of Water Quality Index in Coastal Area (Nagapattinam) of Tamil Nadu, India. Chem Sci Rev Lett, 6(24), 2208-2221. 
Nair IS, Brindha K, Elango L (2021) Assessing the origin and processes controlling groundwater salinization in coastal aquifers through integrated hydrochemical, isotopic and hydrogeochemical modelling techniques. Hydrological Sciences Journal, 66(1), 152-164. https://doi.org/10.1080/02626667.2020.1826490

Nazzal Y, Ahmed I, Al-Arifi NSN, Ghrefat H, Zaidi FK, El-Waheidi MM, Batayneh A, Zumlot T (2014) A pragmatic approach to study the groundwater quality suitability for domestic and agricultural usage, Saq aquifer, northwest of Saudi Arabia. Environmental Monitoring and Assessment, 186(8), 4655-4667. https://doi.org/10.1007/s10661-014-3728-3

Paliwal KV (1972) Irrigation with saline water, Monogram no. 2 (New series). New Delhi, IARI, p 198

Piper AM (1953) A graphic procedure in the geological interpretation of water analysis. Ground water note no. 12, US Geology Survey Department

Ponsingh BA, Maharani K (2015) A Study on Groundwater Quality and Spatial Distribution of Gandarvakottai Taluk by Using GIS. The Asian Review of Civil Engineering, 4(1), 36-41. www.trp.org.in

Prabakaran K, Sivakumar K, Aruna C (2020) Use of GIS-AHP tools for potable groundwater potential zone investigations - a case study in Vairavanpatti rural area, Tamil Nadu, India. Arabian Journal of Geosciences, 13(17), 866. https://doi.org/10.1007/s12517-020-05794-w

Ramachandran A, Sivakumar K, Shanmugasundharam A, Sangunathan, U, Krishnamurthy R (2020) Evaluation of potable groundwater zones identification based on WQI and GIS techniques in Adyar River basin, Chennai, Tamilnadu, India. Acta Ecologica Sinica. https://doi.org/10.1016/j.chnaes.2020.02.006

Roy PD, Selvam S, Venkatramanan S, Logesh N, Lakshumanan C, Sánchez-Zavala JL (2021) Identification of sources and groundwater recharge zones from hydrochemistry and stable isotopes of an agriculture-based paleolacustrine basin of drought-prone northeast Mexico. Geochemistry, December 2020, 125742. https://doi.org/10.1016/j.chemer.2021.125742

Saleh A, Al-Ruwaih F, Shehata M (1999) Hydrogeochemical processes operating within the main aquifers of Kuwait. J Arid Environ 42: 195-209

Sarath Prasanth SV, Magesh NS, Jitheshlal KV, Chandrasekar N, Gangadhar K (2012) Evaluation of groundwater quality and its suitability for drinking and agricultural use in the coastal stretch of Alappuzha District, Kerala, India. Appl Water Sci.https://doi.org/10. 1007/s13201-012-0042-5

Selvam S, Jesuraja K, Venkatramanan S, Chidambaram S, Prasanna Mohan V, Sivakumar K (2021) Delineating saline and fresh water aquifers in Tuticorin of southern India by using geophysical techniques. Environment, Development and Sustainability, 0123456789. https://doi.org/10.1007/s10668-021-01409-w

Sirajudeen J, Manivel V, Manikandan S (2015) Assessment of physic-chemical parameters and water quality index of Viralimalai area near Koraiyar river Pudukkottai district, Tamil Nadu, India. Der Chemica Sinica, 6(1), 1324.Available online at www.pelagiaresearchlibrary.com

Sivakumar K, Priya J, Muthusamy S, Saravanan P, Jayaprakash M (2016) Spatial Diversity of Major Ionic Absorptions in Groundwater: Recent study from the Industrial region of Tuticorin, Tamil Nadu, India. EnviroGeoChimica Acta, 3(1), 138-147. http://www.egcacta.com/AcceptedUpload/160018_20160427213016.PDF 
Sivakumar K, Shanmugasundaram A, Jayaprakash M, Prabakaran K, Muthusamy S, Ramachandran A, Venkatramanan S, Selvam S (2021) Causes of heavy metal contamination in groundwater of Tuticorin industrial block, Tamil Nadu, India. Environmental Science and Pollution Research, 28(15), 18651-18666. https://doi.org/10.1007/s11356-020-11704-0

Srinivasamoorthy K, Gopinath M, Chidambaram S, Vasanthavigar M, Sarma VS (2014) Hydrochemical characterization and quality appraisal of groundwater from Pungar sub basin, Tamilnadu, India. Journal of King Saud University - Science, 26(1), 37-52. https://doi.org/10.1016/j.jksus.2013.08.001

Subba Rao N, Surya Rao P, Venktram Reddy G, Nagamani M, Vidyasagar G, Sathyanarayana NLVV (2011) Chemical characteristics of groundwater and assessment of water quality in Varaha River Basin, Visakhapatnam District, Andhra Pradesh, India. Environ Monit Assess. https://doi.org/10.1007/s10667-011-2333-y

Sundaray SK, Nayak BB, Bhatta D (2009) Environmental studies on river water quality with reference to suitability for agricultural purposes: Mahanadi river estuarine system, India — a case study. Environ Monit Assess 155:227-243

Tindall JA, Petrusak RL, McMohan PB (1995) Nitrate transport and transformation process in unsaturated porous media. J Hydrol 169:51-94

Todd DK (1980) Groundwater hydrology, 2nd edn. John Wiley and Sons, New York, p 535

Venkatramanan S, Chung SY, Ramkumar T, Rajesh R, Gnanachandrasamy G (2016) Assessment of groundwater quality using GIS and CCME WQI techniques: a case study of Thiruthuraipoondi city in Cauvery deltaic region, Tamil Nadu, India. Desalination and Water Treatment, 57(26), 12058-12073. https://doi.org/10.1080/19443994.2015.1048740

WHO (2008) Guidelines for drinking water quality. vol 1. Recommendations, 3rd edn. WHO, Geneva, p 515

Wilcox LV (1955) Classification and Use of Irrigation Waters. USDA, Washington, DC, USA Circular 969. 


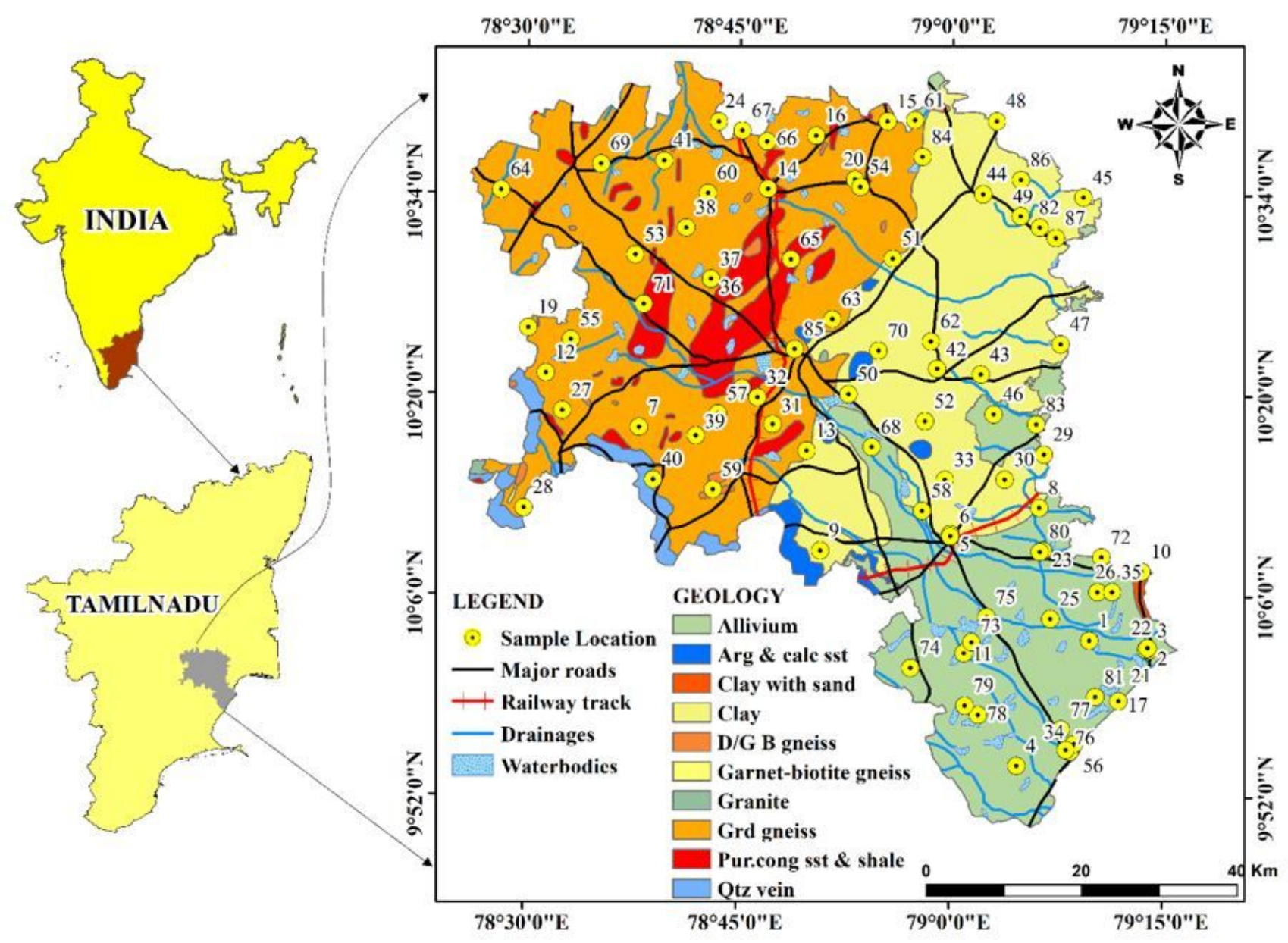

Figure 1

The map shows the study area and sample location Note: The designations employed and the presentation of the material on this map do not imply the expression of any opinion whatsoever on the part of Research Square concerning the legal status of any country, territory, city or area or of its authorities, or concerning the delimitation of its frontiers or boundaries. This map has been provided by the authors. 

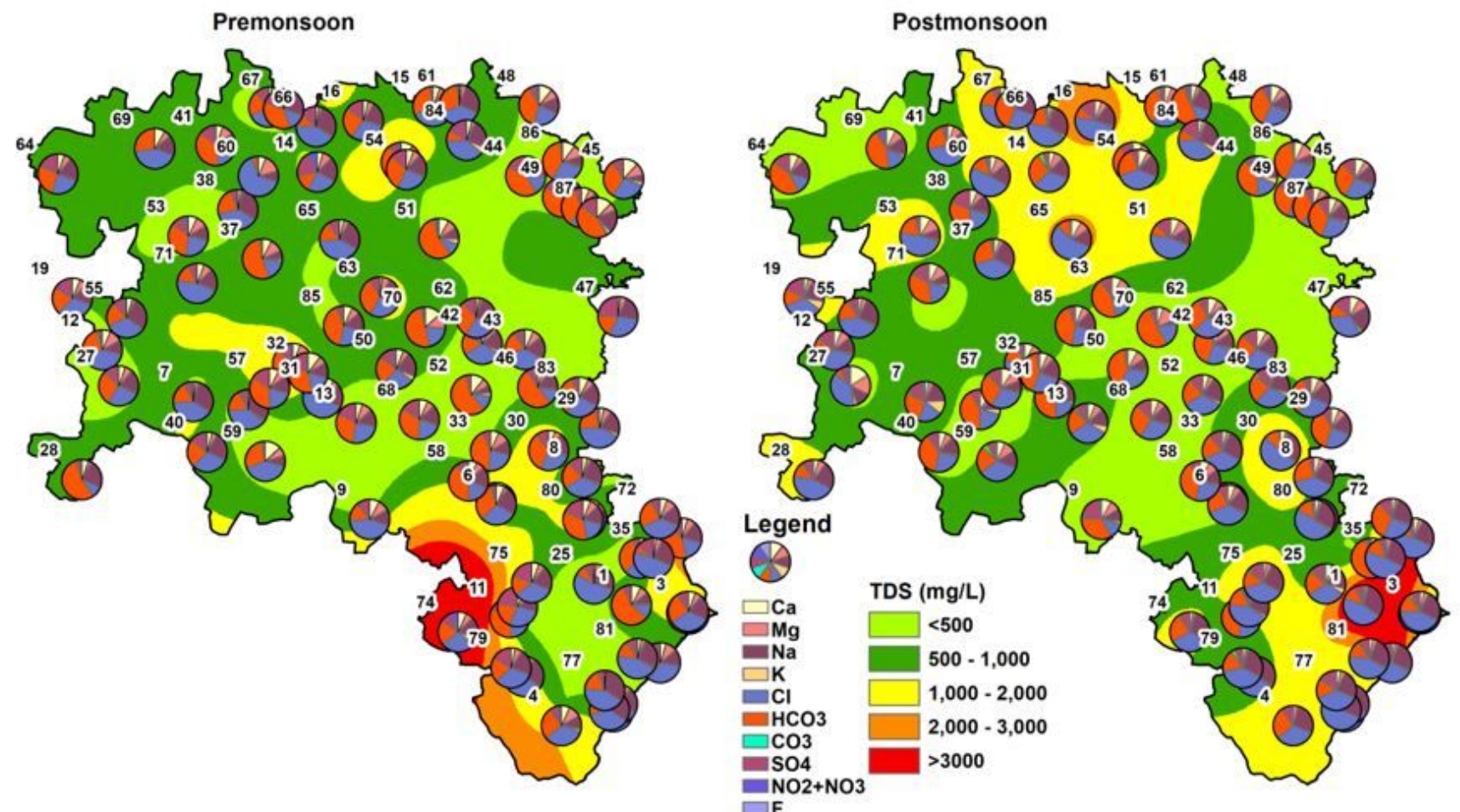

Figure 2

Spatial distribution map shows the TDS with major ions as pie chart Note: The designations employed and the presentation of the material on this map do not imply the expression of any opinion whatsoever on the part of Research Square concerning the legal status of any country, territory, city or area or of its authorities, or concerning the delimitation of its frontiers or boundaries. This map has been provided by the authors. 


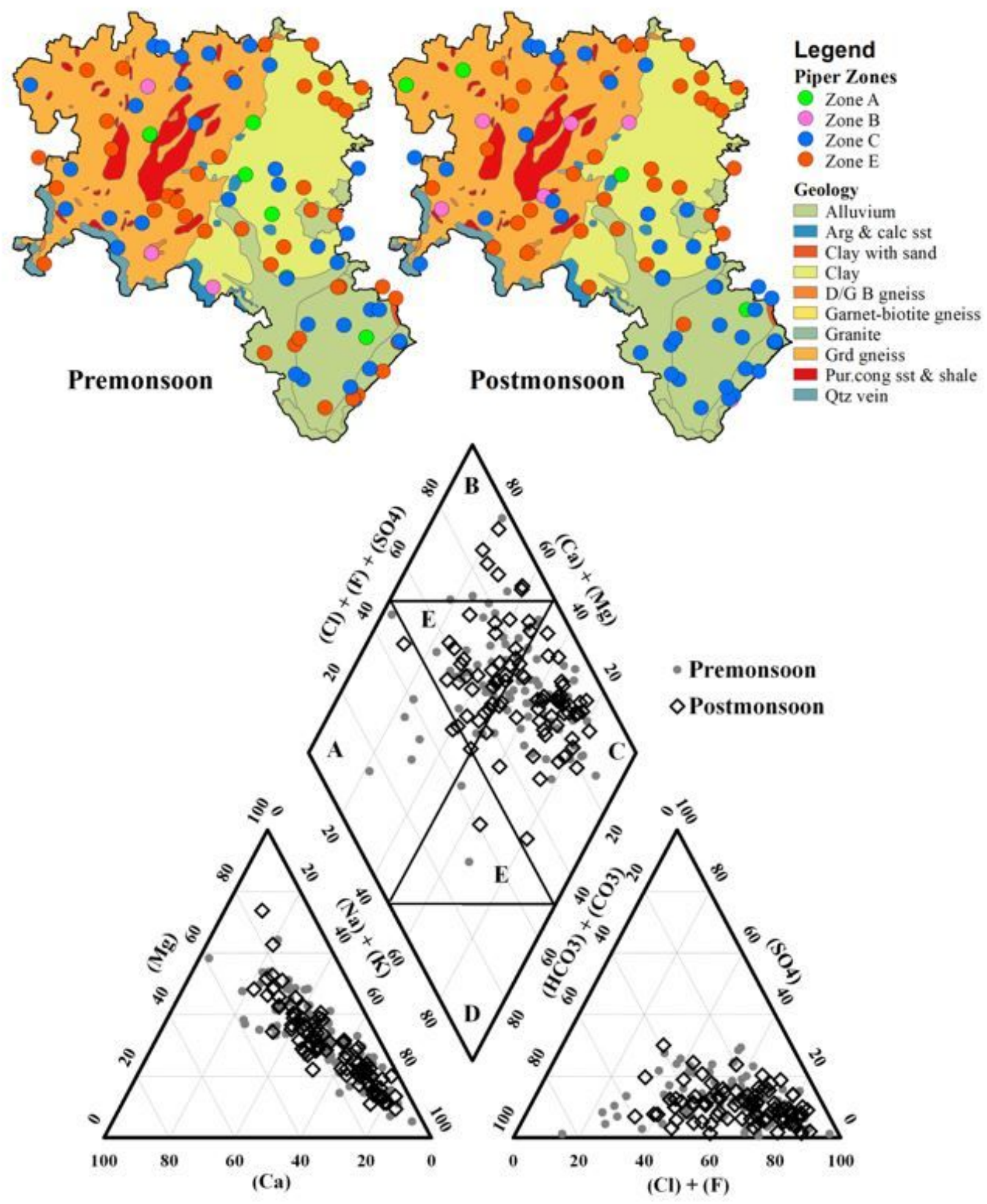

Figure 3

Piper plot for both seasons with spatial distribution maps of hydrological facies Note: The designations employed and the presentation of the material on this map do not imply the expression of any opinion whatsoever on the part of Research Square concerning the legal status of any country, territory, city or area or of its authorities, or concerning the delimitation of its frontiers or boundaries. This map has been provided by the authors. 


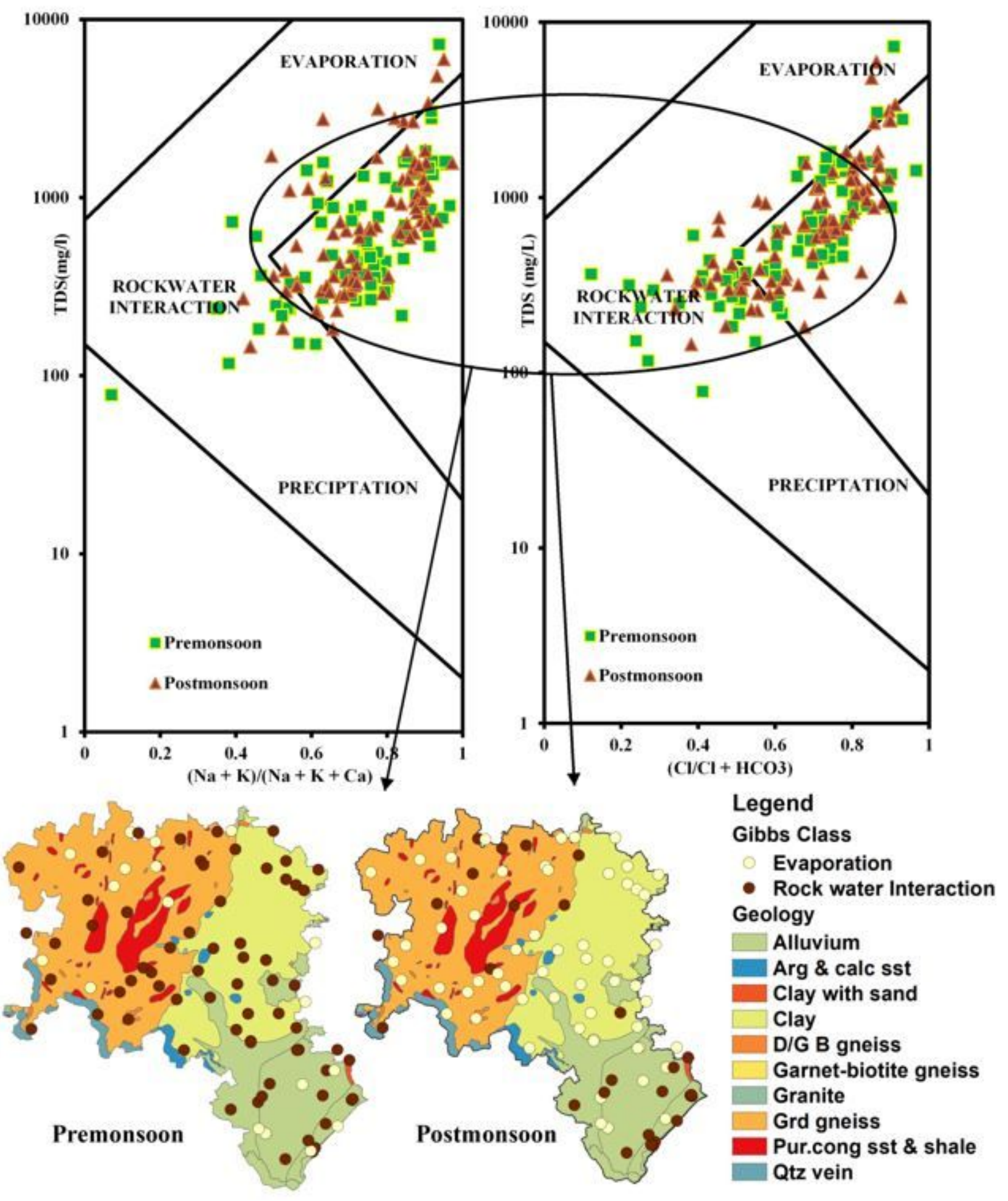

Figure 4

Gibb's plot for both seasons with spatial distribution map of influencing factors Note: The designations employed and the presentation of the material on this map do not imply the expression of any opinion whatsoever on the part of Research Square concerning the legal status of any country, territory, city or area or of its authorities, or concerning the delimitation of its frontiers or boundaries. This map has been provided by the authors. 


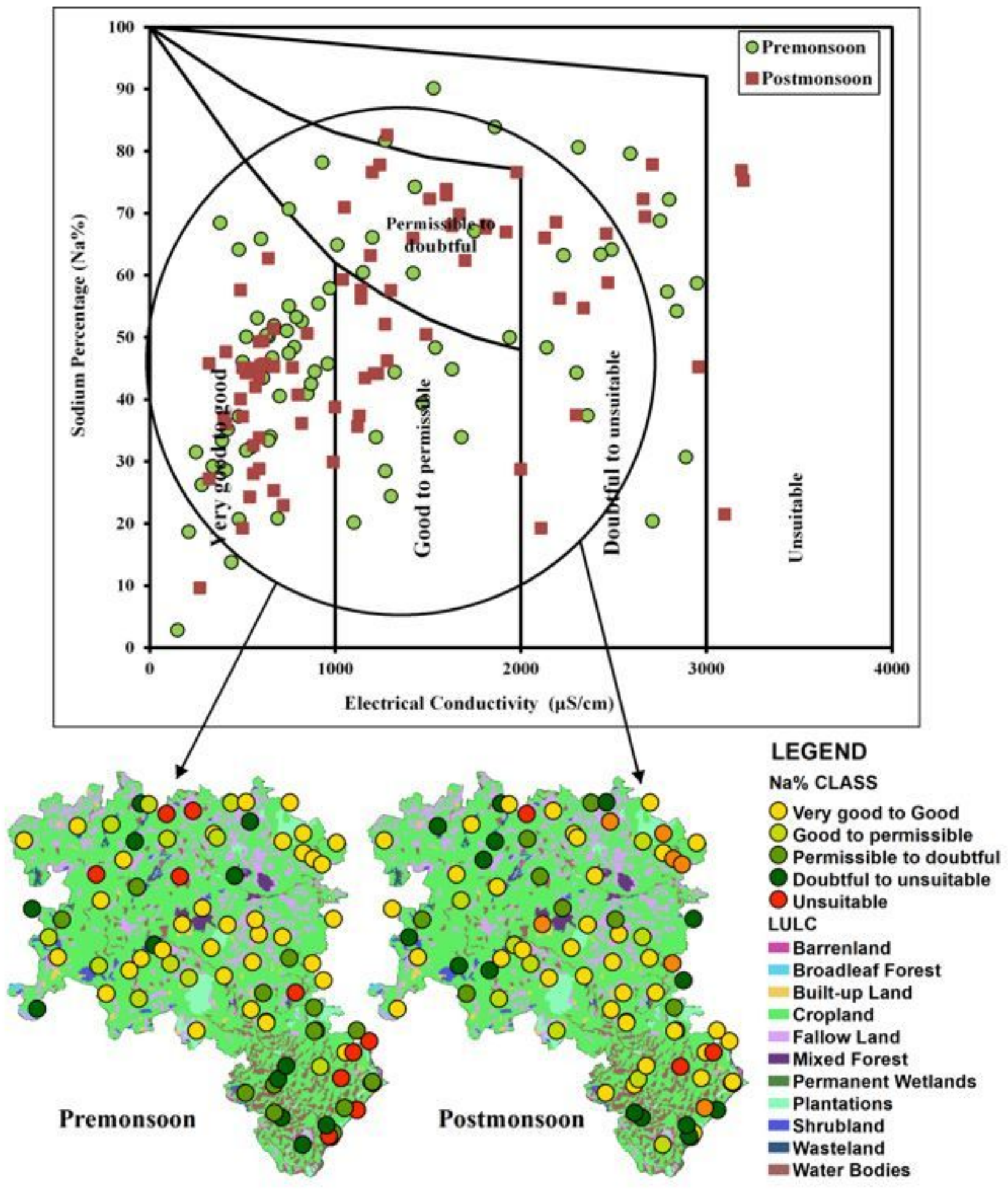

Figure 5

$\mathrm{Na} \%$ vs. EC plot for both seasons with irrigation suitability map Note: The designations employed and the presentation of the material on this map do not imply the expression of any opinion whatsoever on the part of Research Square concerning the legal status of any country, territory, city or area or of its authorities, or concerning the delimitation of its frontiers or boundaries. This map has been provided by the authors. 


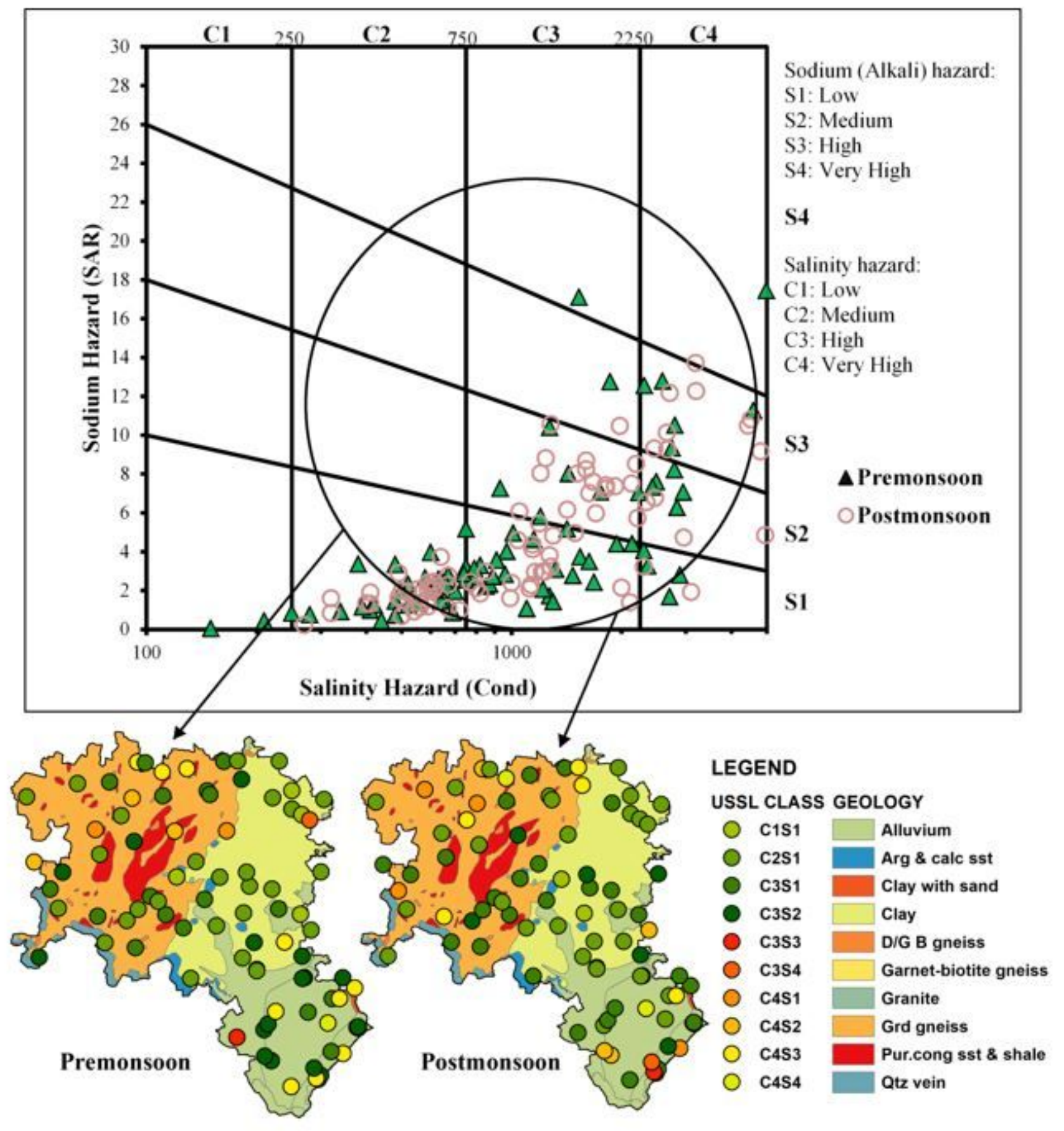

Figure 6

USSL plot for both seasons with spatial distribution map classes 


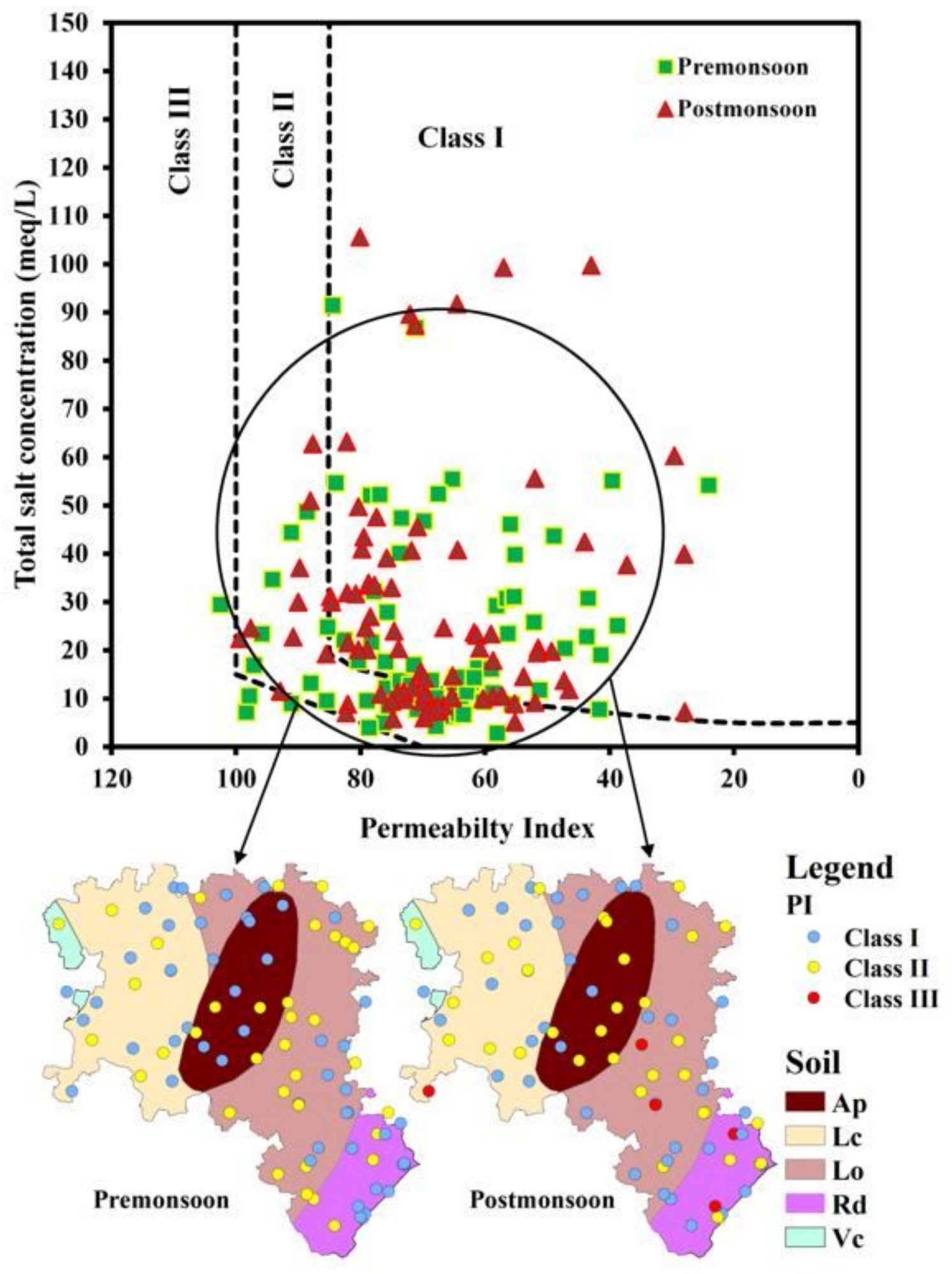

Figure 7

Doneen's PI plot for both seasons with spatial distribution map of classes Note: The designations employed and the presentation of the material on this map do not imply the expression of any opinion whatsoever on the part of Research Square concerning the legal status of any country, territory, city or area or of its authorities, or concerning the delimitation of its frontiers or boundaries. This map has been provided by the authors. 

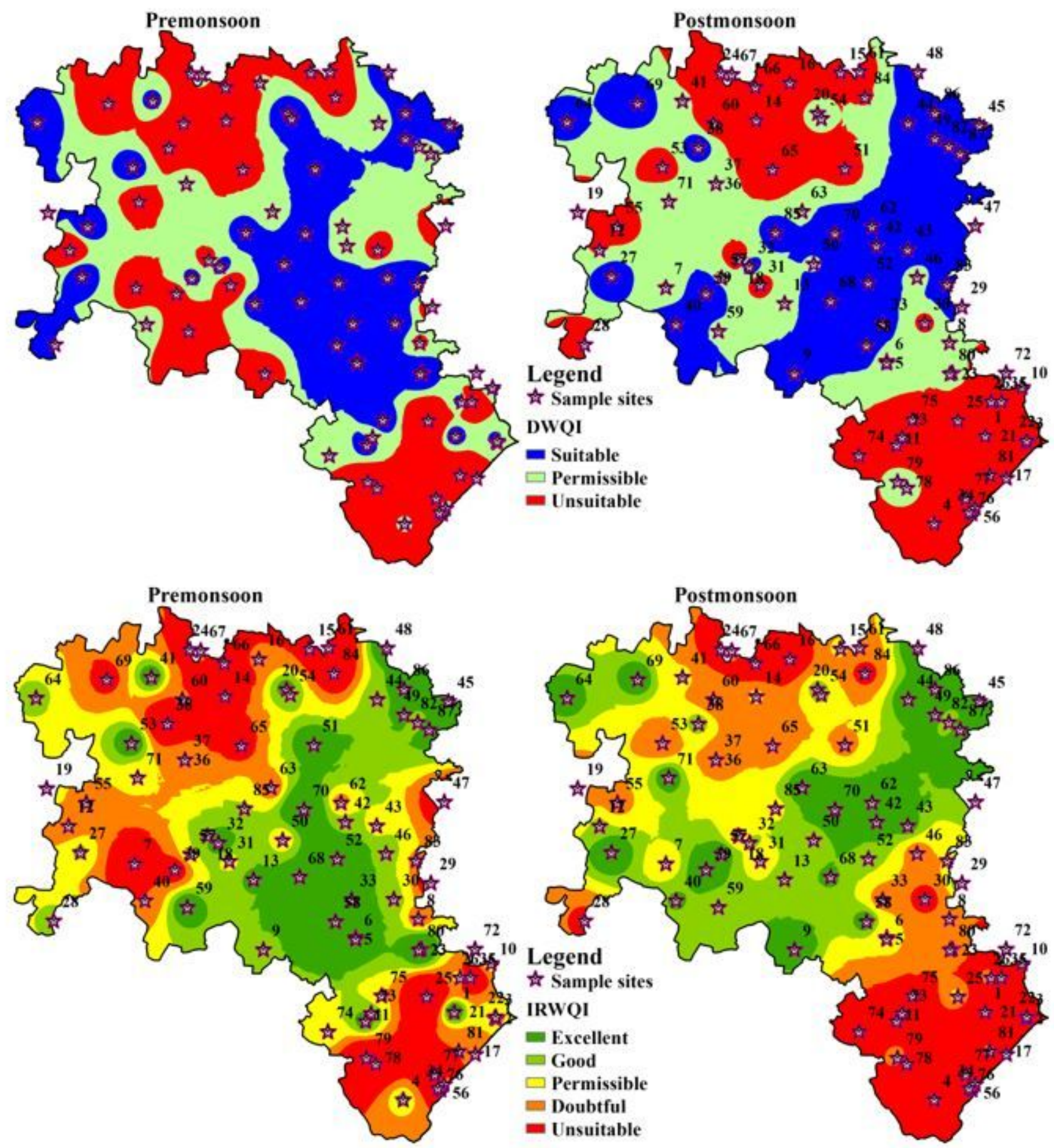

Figure 8

Spatial distribution maps of calculated DWQI \& IRWQI for both seasons Note: The designations employed and the presentation of the material on this map do not imply the expression of any opinion whatsoever on the part of Research Square concerning the legal status of any country, territory, city or area or of its authorities, or concerning the delimitation of its frontiers or boundaries. This map has been provided by the authors. 